\title{
Future projection of greenhouse gas emissions due to permafrost degradation using a simple numerical scheme with a global land surface model
}

Tokuta Yokohata $^{1 *}$ (D), Kazuyuki Saito ${ }^{2}$, Akihiko Ito ${ }^{1}$, Hiroshi Ohno ${ }^{3}$, Katsumasa Tanaka ${ }^{1,4}$, Tomohiro Hajima ${ }^{2}$ and Go Iwahana ${ }^{5}$

\begin{abstract}
The Yedoma layer, a permafrost layer containing a massive amount of underground ice in the Arctic regions, is reported to be rapidly thawing. In this study, we develop the Permafrost Degradation and Greenhouse gasses Emission Model (PDGEM), which describes the thawing of the Arctic permafrost including the Yedoma layer due to climate change and the greenhouse gas $(\mathrm{GHG})$ emissions. The PDGEM includes the processes by which high-concentration GHGs $\left(\mathrm{CO}_{2}\right.$ and $\left.\mathrm{CH}_{4}\right)$ contained in the pores of the Yedoma layer are released directly by dynamic degradation, as well as the processes by which GHGs are released by the decomposition of organic matter in the Yedoma layer and other permafrost. Our model simulations show that the total GHG emissions from permafrost degradation in the RCP8.5 scenario was estimated to be $31-63 \mathrm{PgC}$ for $\mathrm{CO}_{2}$ and $1261-2821 \mathrm{TgCH}_{4}$ for $\mathrm{CH}_{4}\left(68^{\text {th }}\right.$ percentile of the perturbed model simulations, corresponding to a global average surface air temperature change of $0.05-0.11^{\circ} \mathrm{C}$ ), and $14-28{\mathrm{PgC} \mathrm{for} \mathrm{CO}_{2}}$ and $618-1341 \mathrm{TgCH}_{4}$ for $\mathrm{CH}_{4}\left(0.03-0.07^{\circ} \mathrm{C}\right)$ in the $\mathrm{RCP} 2.6$ scenario. GHG emissions resulting from the dynamic degradation of the Yedoma layer were estimated to be less than $1 \%$ of the total emissions from the permafrost in both scenarios, possibly because of the small area ratio of the Yedoma layer. An advantage of PDGEM is that geographical distributions of GHG emissions can be estimated by combining a state-of-the-art land surface model featuring detailed physical processes with a GHG release model using a simple scheme, enabling us to consider a broad range of uncertainty regarding model parameters. In regions with large GHG emissions due to permafrost thawing, it may be possible to help reduce GHG emissions by taking measures such as restraining land development.
\end{abstract}

Keywords: Permafrost degradation, Carbon cycle feedback, Climate change

\section{Introduction}

"Permafrost" is the name given to areas where the ground temperature has remained below $0{ }^{\circ} \mathrm{C}$ for more than 2 years (IPCC 2013). Virtually all soil contains the bodies of dead organisms (mainly plants) in the form of organic matter (Zimov et al. 2006a; Schuur et al. 2008; Brown 2013). When the soil is not frozen, the organic

\footnotetext{
*Correspondence: yokohata@nies.go.jp

${ }^{1}$ Center for Global Environmental Research, National Institute for Environmental Studies, 16-2 Onogawa, Tsukuba 305-8506, Japan Full list of author information is available at the end of the article
}

matter is decomposed by microorganisms and released from the surface to the atmosphere in the form of carbon dioxide or methane (Zimov et al. 2006b; Walter et al. 2007; Ciais et al. 2013). However, when the soil is frozen, the organic matter is trapped without being decomposed, as the activity of these microorganisms is suppressed (Brown 2013; Hugelius et al. 2013; Hugelius et al. 2014). It is estimated that permafrost contains roughly twice the amount of carbon as the air and approximately three times as much as land plants (Prentice et al. 2001; Ping et al. 2008; Tarnocai et al. 2009; Dlugokencky and Tans 2013). As the Earth's 
surface temperature rises due to climate change, the frozen soil in the polar region will thaw, thereby releasing in the form of greenhouse gases (GHGs) the organic substances contained in the frozen soil (Collins et al. 2013; Koven et al. 2013; Schuur et al. 2015). These GHGs will further accelerate global warming (Lenton 2012; Köhler et al. 2014; Schuur et al. 2015). Given the large amount of carbon contained in the permafrost, positive feedback from permafrost thawing is very likely to accelerate changes in the climate system (Schaefer et al. 2014; Koven et al. 2015; MacDougall et al. 2015; Schneider von Deimling et al. 2015; MacDougall and Knutti 2016; Steffen et al. 2018; Gasser et al. 2018; McGuire et al. 2018; Kawamiya et al. 2020).

Still, there is a great deal of uncertainty regarding the process of GHG emissions from permafrost thawing (Schaefer et al. 2014). This is partly due to the lack of observational knowledge of basic permafrost processes (Schuur et al. 2015). Although permafrost exists in various forms depending on its formation factors, what has been attracting attention in recent years is the thawing of the Yedoma layer, a permafrost layer containing a large mass of ground ice, mostly found in Alaska and Siberia (Strauss et al. 2013; Strauss et al. 2017). It has long been known that the Yedoma layer exists in permafrost zones (Brouchkov and Fukuda 2002; Schirrmeister et al. 2011; Kanevskiy et al. 2011), but it has only recently been noted that this huge underground layer is thawing rapidly (Vonk et al. 2012; Ulrich et al. 2014; Strauss et al. 2017). Analysis of satellite observations suggest that a subsidence of the ground occurred at sites where tundra fires have caused the heat insulation effect of vegetation on the surface to disappear (Iwahana et al. 2016) and that frozen soil and ground ice are being degraded by erosion from rivers and ocean waves (Günther et al. 2013; Jones et al. 2011; Kanevskiy et al. 2016). Previous studies have reported that the ground ice and frozen soils in the Yedoma layer contain high concentrations of carbon dioxide, methane, and organic carbon (e.g., Saito et al. 2017; Strauss et al. 2017). To date, however, the impact on the climate system of the dynamic degradation of the Yedoma layer associated with ground subsidence has not been sufficiently evaluated, partly due to the difficulty of modeling it in global climate models (Schneider von Deimling et al. 2015).

In this study, we developed a simple scheme to describe the thawing process of the Yedoma layer accompanied by vertical mechanical collapse due to ground subsidence (hereinafter called "dynamic degradation") based on in-situ observations conducted in Alaska and Siberia. Using this model, we estimate the GHG emissions due to the future degradation of the Yedoma layers. We consider two pathways for GHG emissions due to permafrost degradation: the process of releasing GHGs $\left(\mathrm{CO}_{2}\right.$ and $\left.\mathrm{CH}_{4}\right)$ trapped in the frozen soil (referred to as "direct emissions") and the process of releasing GHG emissions produced by the decomposition of organic matter contained in the frozen soil ("secondary emissions") caused by the thawing of the permafrost. In addition to the dynamic degradation of the Yedoma layers, we also estimate the GHG emissions due to the thermodynamic degradation of the permafrost owing to the increase in ground temperature. Finally, in the course of our study, we estimate the global mean temperature response caused by the GHG emissions due to permafrost degradations using the simple climate model ACC2 (Tanaka and O'Neill 2018).

\section{Methods}

Permafrost Degradation and Greenhouse gasses Emission Model (PDGEM) evaluates the GHG emissions due to the degradation of the permafrost layer. PDGEM describes the processes of dynamic (Section 2.1.1) and thermodynamic (Section 2.1.2) permafrost degradation with a simple formulation and calculates the GHG emissions globally with a resolution of 1 degree. The parameters used in the formulation are varied (Table 1) in order to describe the future possible behavior of permafrost degradations. Details of the model formulation and experimental settings for the future projections are summarized in the sections that follow.

\subsection{Description of Permafrost Degradation and GHG Emission Model}

\subsubsection{Dynamic degradation of the Yedoma Layer}

$F_{D y}\left[\mathrm{~kg} \mathrm{year}^{-1}\right]$, the GHG emissions due to the dynamic degradation of the Yedoma layer, is defined as

$$
F_{D y}=F_{D y, d i r}+F_{D y, \text { sec }}
$$

$F_{D y}$, dir: GHG emissions due to the release of gases trapped in the frozen soil $\left[\mathrm{kg} \mathrm{year}^{-1}\right]$

$F_{D y \text {, sec }}:$ GHG emissions due to the decomposition of organic matter $\left[\mathrm{kg} \mathrm{year}^{-1}\right]$

The first term in Eq. (1) corresponds to direct emissions, while the second term represents secondary emissions due to dynamic degradation. The direct emissions are formulated as follows:

$$
F_{D y, d i r}=\Delta V_{D y} \times X_{\mathrm{GHG}} .
$$

$\Delta V_{D y}$ : Volume of thawed permafrost due to dynamic degradation $\left[\mathrm{m}^{3}\right.$ year $\left.^{-1}\right]$

$X_{G H G, i}$ : GHG mass in thawed permafrost $\left[\mathrm{kg} \mathrm{m}^{-3}\right]$

Observational studies have measured the settling velocity of the ground surface due to permafrost thawing in the area where fire has occurred (e.g., Iwahana et al. 2016). In this study, the volume of dynamic permafrost 
Table 1 Model parameters for the calculation of GHG emissions due to the dynamic and thermodynamic permafrost degradations

\begin{tabular}{|c|c|c|c|c|}
\hline Model parameter & Variable & Standard value & Uncertainty range & References \\
\hline$V_{\text {dstrb }}[\mathrm{cm} / \mathrm{yr}]$ & Subsidence velocity of burnt area in Yedoma layer & 2.4 & \pm 2.1 & a \\
\hline$r_{i c e}$ & Ice contents in Yedoma layer & 0.64 & \pm 0.15 & $b$ \\
\hline$d_{S O C}[\mathrm{~m}]$ & Depth of average soil organic layer & 3.0 & \pm 1.5 & $c$ \\
\hline$\pi$ & $\begin{array}{l}\text { Fraction for the flux of soil organic carbon, fast } \\
\text { pool slow pool }\end{array}$ & $\begin{array}{l}0.025 \\
0.45\end{array}$ & $\begin{array}{l}0.01-0.04 \\
0.30-0.60\end{array}$ & $d, e, f, g, h, i$ \\
\hline$\tau$ [year] & Time scale for slow decomposition at $5{ }^{\circ} \mathrm{C}$ & 25 & $10-40$ & $d, e, f, h$ \\
\hline$\Delta r_{w t i n d, \max }[\%]$ & Maximum increase of wetland fraction & 20 & $10-30$ & $d$ \\
\hline Q10 & $\begin{array}{l}\text { Temperature sensitivity parameter, } \\
\text { aerobic } \\
\text { anaerobic }\end{array}$ & $\begin{array}{l}2.5 \\
3.0\end{array}$ & $\begin{array}{l}1.5-3.5 \\
4.0-6.0\end{array}$ & $d, i, j$ \\
\hline$r_{\text {gas }}$ & $\begin{array}{l}\mathrm{GHG} \text { production ratio, } \mathrm{CH}_{4}: \mathrm{CO}_{2} \text { in aerobic } \\
\mathrm{CH}_{4}: \mathrm{CO}_{2} \text { in anaerobic } \\
\text { Fast pool } \\
\text { Slow pool }\end{array}$ & $\begin{array}{l}1: 50 \\
1: 1 \\
1: 7\end{array}$ & $\begin{array}{l} \pm 50 \% \\
\pm 20 \% \\
\pm 50 \%\end{array}$ & $k, m, n, p$ \\
\hline oxd & $\mathrm{CH}_{4}$ oxidation rate, anaerobic & 0.20 & $0.15-0.40$ & h \\
\hline
\end{tabular}

The standard values and uncertainty ranges of the parameters are shown. References for the standard values and uncertainty ranges are as follows. a: Iwahana et al. (2016), b: Strauss et al. (2017), c: Saito et al. (2020), d: Schneider von Deimling et al. (2015), e: Sitch et al. (2003), f: Dutta et al. (2006), g: Koven et al. (2011), h: Burke et al. (2012), i: Schadel et al. (2014), j: Walter and Heimann (2000), k: Lee et al. (2012), m: Schuur et al. (2008), n: Segers (1998), p: Walter Anthony et al. (2014)

thawing is formulated based on this observational knowledge as follows:

$$
\Delta V_{D y}=P_{d s t r b} \times A_{y d m} \times V_{d s t r b} .
$$

$P_{d s t r b}:$ Probability of occurrence of fire

$A_{y d m}$ : Area of Yedoma layer in a 1-degree grid cell $\left[\mathrm{m}^{2}\right]$

$V_{d s t r b}$ : Settling velocity of the ground due to permafrost thawing $\left[\mathrm{m} \mathrm{year}^{-1}\right]$

Equation (2) describes the processes of permafrost thawing with land subsidence owing to the occurrence of fire. We determine the fire area in the Yedoma layer with the first and second terms $\left(P_{d s t r b} \times A_{y d m}\right)$ in Eq. (3). The probability of fire, $P_{d s t r b}$, is given as a function of meteorological data based on the observed relationship between past occurrences of fires and meteorological conditions. Veraverbeke et al. 2017 showed high correlations between fire occurrence and temperature, total precipitation and convective precipitation in the Northwest territory (NT) and Alaska (AK) from 2001 to 2015. In this study, the future fire area ratio, $P_{d s t r b}$, is estimated using future meteorological data and the relationship shown below:

$$
P_{d s t r b}=a+b \times T_{\text {air }}+c \times P_{\text {total }}+d \times P_{\text {conv }}
$$

where $T_{\text {air }}$ is surface air temperature $[\mathrm{K}], P_{\text {total }}$ is total precipitation $\left[\mathrm{kg} / \mathrm{m}^{2} / \mathrm{s}\right]$, and $P_{\text {conv }}$ is convective precipitation $\left[\mathrm{kg} / \mathrm{m}^{2} / \mathrm{s}\right]$, and the coefficients are $a=-0.495, b=$ 0.00179, $c=-343.6, d=204.4$. The coefficients in Eq. (4) are obtained using multiple regression of the fire area ratios for 2001-2015 in NT and AK, from Veraverbeke et al. 2017, and NCEP reanalysis data (Kalnay et al.
1996) for the same regions. To estimate the future fire area ratio, the bias of the global climate models (GCMs, details of which are explained later) is corrected with NCEP reanalysis data (Kalnay et al. 1996) by subtracting the climatological error (the difference between model results and the reanalysis data using 1980-2000 average). As a result of this bias correction, the estimated fire area ratio based on Eq. (4) is consistent with past observations (Veraverbeke et al. 2017). Given that Veraverbeke et al. 2017 found correlation based on the NT and AK regions, we estimate the future fire area ratio by averaging the climate model data at 10-degree resolution. We also confirmed that the difference between the estimated value of the fire area obtained by Eq. (4) and the observed value (Veraverbeke et al. 2017) has a normal distribution (not shown, with standard deviation = 0.00229). Considering that fires generally occur stochastically, a normal distribution with the above standard deviation, corresponding to the difference between the estimated and observed fire area ratio, was used to randomly assign values to each 1-degree grid.

With respect to the area of the Yedoma layer, $A_{y d m}$, we use the results of Saito et al. (2020) regarding the behavior of soil moisture and organic carbon from the last interglacial period (approximately 120,000 years ago) to the present with $20 \mathrm{~km}$ resolution. Since the Yedoma layer is considered to be a region where soil frozen water and soil organic carbon are particularly concentrated (e.g., Strauss et al. 2017), in this study, we defined the Yedoma layer by using a threshold value for soil frozen water and soil organic carbon as calculated in Saito et al. 2020. We based our threshold value on the "vulnerability" measure defined in Saito et al. 2020 as (ICE/ 
$\max (\mathrm{ICE}) \times \mathrm{SOC} / \max (\mathrm{SOC}))$, where $\mathrm{ICE}$ and $\mathrm{SOC}$ are soil frozen water and soil organic carbon, respectively, and "max" denotes the maximum value across the spatial dimension. According to Strauss et al. 2017, the soil organic carbon in the Yedoma layer is estimated to be $83-129 \mathrm{GtC}$. In this study, the threshold of vulnerability was chosen so that the soil organic matter of the Yedoma layer falls within the range of Strauss et al. 2017 (Table 1).

The settling velocity, $V_{d s t r b}$, in Eq. (2) is defined based on observational studies. Table 1 of Iwahana et al. 2016 synthesized the annual ground subsidence rates at various fire-burnt sites. In this study, the average value of Iwahana et al. 2016 is used; the range of the sedimentation velocity over the fire-bunt region is $2.4 \pm 2.1 \mathrm{~cm} /$ year, as shown in Table 1.

The GHG concentration, $X_{G H G}$, in Eq. (1) can be expressed by the following equation:

$$
X_{G H G}=R_{\text {pore }} \times C_{G H G} \times \rho_{G H G} .
$$

$R_{\text {pore }}$ : Volume fraction of bubbles in the permafrost [ratio]

$C_{G H G}$ : GHG concentration in the permafrost pores [ratio]

$\rho_{\text {GHG }}:$ Mass density of GHG $\left[\mathrm{kg} \mathrm{m}^{-3}\right]$

In this study, we consider $\mathrm{CO}_{2}$ and $\mathrm{CH}_{4}$ as the GHG emissions and use data obtained by field observation in the Yedoma layer in Alaska and Siberia (Saito et al. 2017) to set the values of $R_{\text {pore }}$ and $C_{G H G}$. As reported in Saito et al. 2017, the $R_{\text {pore }}$ and $C_{G H G}$ values obtained by field observation have very large variation. Table 2 shows the standard deviation of the observed values in Saito et al. 2017. In calculating the dynamic degradation, the average value for the ground ice and frozen soil is used for the calculation of $X_{G H G}$. It is reported that the ice content in the Yedoma layer $\left(r_{\text {ice }}\right)$ is approximately 0.64 (Strauss et al. 2017). Accordingly, the ratios of ground ice and frozen soil ( $r_{\text {ice }}$ and $1-r_{\text {ice }}$, respectively) are used as multipliers for $R_{\text {pore }}$ and $C_{\mathrm{GHG}}$. Field observations revealed that the layer with high GHG concentration (Table 2) was above (approximately) $5 \mathrm{~m}$ in the soil column and that the lower layer had very low GHG concentration. In this study, therefore, we assume that the GHG concentration, as shown in Table 2, is zero below $5 \mathrm{~m}$.

In order to estimate the GHG emissions associated with the decomposition of soil organic carbon due to the dynamic degradation of permafrost ( $F_{D y \text {, sec }}$ in Eq.1), this study considers four types of decomposition, following Schneider von Deimling et al. 2015 and Gasser et al. 2018. Specifically, we differentiate decomposition types based on two types of organic matter quality (fast or slow) and two types of soil moisture conditions (aerobic or anaerobic). The following equations for the decomposition of thawed permafrost carbon are solved with a global resolution of 1 degree:

$$
\frac{d C_{\text {thaw }}^{i, j}}{d t}=\pi^{i, j} F_{\text {thaw }}-\frac{R^{j}}{\tau^{i}} C_{\text {thaw }}^{i, j}
$$

$i$ : index for the quality of soil organic matter (fast or slow decomposition)

$j$ : index for the soil moisture state (aerobic and anaerobic decomposition)

$C_{\text {thaw }}^{i, j}$ : soil organic carbon content in the thawed permafrost $[\mathrm{kg}]$

$F_{\text {thaw: }}$ flux of soil organic carbon due to permafrost thawing $[\mathrm{kg} /$ year]

$\pi^{i, j}$ : fraction of flux for the corresponding types

$\tau^{i}$ : turnover time of soil organic carbon [year]

$R^{j}$ : changes in soil organic carbon decomposition rate due to temperature rise

The model parameter, $\pi^{i, j}$, i.e., the fraction of thawed soil organic carbon, depends on the quality of organic matter ( $i=1$ : fast, $i=2$ : slow decomposition) and soil water content ( $j=1$ : aerobic, $j=2$, anaerobic). The quality of organic matter is an important determinant for the timescale of the carbon release (Strauss et al. 2015). We subdivide the thawed permafrost carbon into a fast and slow decomposing fraction with annual and decadal timescales $\left(\tau^{i}\right)$ based on the literature of soil organic quality, as shown in Table 1 (Sitch et al. 2003; Dutta et al. 2006; Koven et al. 2011; Burke et al. 2012; Schädel et al. 2014).

The soil water content is also a key determinant in the decomposition of soil organic carbon. In this study, the fraction of thawed permafrost carbon under the aerobic or anaerobic condition is determined by the wetland fraction, $r_{w t l n d}$, obtained from the Global Lakes and Wetland Database (Lehner and Döll 2004). The original wetland fraction map is interpolated into 1-degree grid cells. The fraction of soil organic carbon for aerobic decomposition is $1-r_{w t l n d}$, while that for anaerobic decomposition is $r_{w t l n d}$ in each grid cell. In the future

Table 2 Volume fraction of air bubbles in the ground ice and frozen soil $\left(R_{\text {pore }}\right)$ and the concentration of $G H G$ s in the air bubbles

$\left(C_{G H G}\right)$

\begin{tabular}{lllll}
\hline Variable & $\mathrm{CO}_{2} /$ ground ice & $\mathrm{CH}_{4} /$ ground ice & $\mathrm{CO}_{2} /$ frozen soil & $\mathrm{CH}_{4} /$ frozen soil \\
\hline$R_{\text {pore }}[\mathrm{cc} / \mathrm{cc}]$ & $0.044(0.021)$ & $0.031(0.004)$ & $0.019(0.010)$ & $0.014(0.0074)$ \\
$C_{\mathrm{GHG}}[\mathrm{ppmv}]$ & $2992(5101)$ & $21848(38434)$ & $7714(11933)$ & $131675(139746)$ \\
\hline
\end{tabular}

The average value and standard deviation for $\mathrm{CO}_{2}$ and $\mathrm{CH}_{4}$ are shown 
simulations, extensions of the wetland area are represented as a function of surface air temperature rise, with reference to Schneider von Deimling et al. 2015. Specifically, we describe the increase in $r_{w t l n d}$ by linear scaling with the surface air temperature anomaly, $\Delta T_{a}$ (the anomaly is calculated as the difference from the first 20years average). The wetland fraction reaches its maximum extent $\left(\Delta r_{w t l n d, \max }\right)$ for a warming $\Delta T_{a}$ of $10 \mathrm{~K}$. For further warming, the wetland fraction is kept constant at the maximum extent. The uncertainty range of $\Delta r_{w t l n d}$, max is shown in Table 1.

The flux of soil organic carbon due to permafrost thawing is formulated as

$$
F_{\text {thaw }}=\Delta V_{D y} \times \rho_{S O C}
$$

Here, $\rho_{S O C}$ is the density of soil organic carbon, calculated as $\rho_{S O C}=\frac{\sigma_{S O C}}{d_{S O C}}$, where $\sigma_{S O C}$ is the soil organic carbon from Saito et al. 2020, and $d_{S O C}$ is the depth of the soil organic carbon. $d_{S O C}$ is a model parameter in the range shown in Table 1 . The changes in soil organic carbon decomposition rate due to temperature change are formulated with reference to Schneider von Deimling et al. 2015 as follows:

$$
R^{j}=Q 10^{j\left(T_{g}-10\right) / 10}
$$

Q10': temperature sensitivity parameter

$T_{g}$ : soil temperature $\left[{ }^{\circ} \mathrm{C}\right]$

Q10 is the temperature sensitivity of carbon decomposition due to the microbial soil activity rises that accompany increasing soil temperature. The $Q 10^{\prime}$ parameter is dependent on the aerobic or anaerobic conditions; the parameter ranges are given based on the literature, as shown in Table 1 (Walter and Heimann 2000; Shadel et al. 2013; Schneider von Deimling et al. 2015). For $T_{g}$, we use monthly mean soil temperature (averaged over the top $4 \mathrm{~m}$ ), calculated by land-surface model simulations with 1-degree resolution (Yokohata et al. 2020a, 2020b). The details of this are explained in Section 2.2.

The GHG emissions due to the decomposition of soil organic carbon, $F_{D y}$, sec , can be calculated by solving $C_{\text {thaw }}^{i, j}$ in Eq. (5) as follows:

$$
F_{D y, \text { sec }}=\sum_{i, j}\left(\frac{d C_{\text {thaw }}^{i, j}}{d t}-\pi^{i, j} F_{\text {thaw }}\right) \times r_{\text {gas }}^{i, j}\left(1-o x d^{j}\right)
$$

$r_{\text {gas }}^{i, j}$ : production ratio of GHG $\left(\mathrm{CO}_{2}\right.$ or $\left.\mathrm{CH}_{4}\right)$ due to soil organic matter decomposition

$o x d^{j}$ : oxidation rate of $\mathrm{CH}_{4}$

The production rate of $\mathrm{CO}_{2}$ and $\mathrm{CH}_{4}, \quad r_{\text {gas }}^{i, j}$, is dependent on the soil organic quality and aerobic or anaerobic conditions. The ranges of the parameter values for $r_{\text {gas }}^{i, j}$ are determined based on incubation studies under various conditions (Segers 1998; Schuur et al.
2008; Lee et al. 2012; Walter Anthony et al. 2014; Schneider von Deimling et al. 2015). The $o x d^{j}$ term corresponds to the fraction of released carbon that is oxidized (thus, $o x d^{j}=0$ for $\mathrm{CO}_{2}$ ), the range of which is determined from the literature (Burke et al. 2012; Schneider von Deimling et al. 2015).

\subsubsection{Thermodynamic degradation of the permafrost layer}

In this section, the thermodynamic degradation of the permafrost (i.e., the thickening of the active layer) due to the rise in soil temperature in future climate change is formulated. In the formulation for the dynamic degradation of the Yedoma layer (Eq.1), direct emissions are considered due to the presence of high-concentration GHGs (Table 1). However, direct emissions are not considered in the thermodynamic degradation since high-concentration GHGs are not expected to be present in the permafrost other than in the Yedoma layer. Even in the thermodynamic degradation, (Eqs. 5, 6,7 and 8 ) is used for the formulation of the secondary GHG release. To establish the flux of soil organic carbon due to the permafrost thawing associated with thermodynamic degradation, Eq. (6) is replaced by

$$
F_{\text {thaw }}=\Delta V_{t h r} \times \rho_{S O C}
$$

$\Delta V_{D y}$ : Volume of thawed permafrost due to thermodynamic degradation $\left[\mathrm{m}^{3}\right.$ year $\left.^{-1}\right]$

Here, we use the same $\rho_{S O C}$ as described in Eq. (6). For the volume of thawed permafrost due to thermodynamic degradation, numerical simulations using a global landsurface model (Yokohata et al. 2020a, 2020b) are used. The formulation for $\Delta V_{T h}\left[\mathrm{~m}^{3} \mathrm{yr}^{-1}\right]$ in the th year is as follows:

$$
\begin{aligned}
\Delta V_{T h}= & {\left[A L T(t)-\operatorname{MAX}\left(A L T\left(t_{0}\right), t_{0}=0, \ldots t-1\right)\right] } \\
& \times A_{\text {grid }} .
\end{aligned}
$$

Here, $A L T(t)$ is the active layer thickness [m] (ALT, the annual maximum thaw depth) in the $t$ th year. The active layer is defined as the region where the ground temperature exceeds $0{ }^{\circ} \mathrm{C}$ in summer seasons. Eq. (10) is formulated in order to avoid counting the thawed region multiple times due to the annual variability of ALT. $A_{\text {grid }}$ in Eq. (10) is the grid area of the global climate model used for the simulation (1-degree latitude and longitude) as described in the next section. If Eq. (10) produces a negative value, $\Delta V_{T h}$ is set to zero.

\subsection{Experimental setting}

Table 2 shows the standard values and uncertainty ranges for all parameters given in this study, as explained in the previous sections. Each parameter was randomly selected from the uniform distribution with the uncertainty range shown in Table 2. In all, 500 
simulations were performed using the randomly selected parameters.

In addition to the parameters shown in Table 2, one of the physical variables used in the Permafrost Degradation and Greenhouse gasses Emission Model (PDGEM) model is the soil temperature, $T_{g}$, which is used for changes in the soil decomposition rate (Eq. 7) and the volume of the thermodynamic permafrost thawing (Eq. 9). $T_{g}$ is calculated by the global land-surface climate model MIROCINTEG-LAND (MIROC INTEGrated LAND surface model, Yokohata et al. 2020a, 2020b), which is based on the land surface components of the global climate model MIROC (Model for Interdisciplinary Research on Climate; Watanabe et al. 2010; Takata et al. 2003). The results of multi-GCM simulations provided by the Inter-Sectoral Impact Model Inter-comparison Project phase 1 (ISIM IP1, Hempel et al. 2013) were used as the atmospheric forcings to drive this land surface model. Using atmospheric forcings generated by the five GCMs (GFDLES2M, Dunne et al. 2012; HadGEM2-ES, Jones et al. 2011; IPSL-CM5A-LR, Dufresne et al. 2013; Nor-ESM, Bentsen et al. 2013; MIROC-ESM-CHEM, Watanabe et al. 2011) of ISIMIP1, we performed historical simulations (19512005) and future simulations (2006-2100) based on representative concentration pathways (RCP, van Vuuren et al. 2011) RCP2.6 and RCP8.5. The resolution of the land surface model was 1 degree (Nitta et al. 2014). In this study, a model version with improved permafrost processes (Yokohata et al. 2020b) was used.

Another physical variable given to the PDGEM model was the future temperature change, $\Delta T_{a}$, which is used for the future extent of the wetland area. We use the future projections of the five ISIMIP1 GCMs (Hempel et al. 2013) noted above, under the RCP2.6 and RCP8.5 scenarios for $\Delta T_{a}$.

The GHG emissions due to the dynamic and thermodynamic permafrost thawing are calculated with the model parameters shown in Table 2. The GHG emissions are then integrated globally and given to a simplified climate model, ACC2 (Tanaka and O'Neill 2018), which calculates the global mean surface air temperature response to GHG emissions. By calculating the global mean surface air temperature response with and without the permafrost GHG emissions under RCP 8.5, the impact of permafrost thawing on the climate system can be examined.

\section{Results and discussion}

Figure 1 shows the area ratio of the Yedoma layer and the distribution of soil organic carbon used to calculate the dynamic degradation. As described in the previous section, this study defines the Yedoma layer as permafrost having a particular abundance of soil organic carbon and soil frozen water, based on data from Saito et al. (2020). The total soil organic carbon in the Yedoma layer, as shown in Fig. 1, is consistent with the estimates of Strauss et al. 2017 (106 GtC, the middle of uncertainty range 83-129 GtC). Soil organic carbon in the Arctic has accumulated in cold and humid environments where soil degradation is slow. It is distributed in eastern Siberia and Alaska, found mostly in coastal areas and near river basins (Saito et al. 2020). These areas are characterized by extremely low temperatures (Yokohata et al. 2020b).

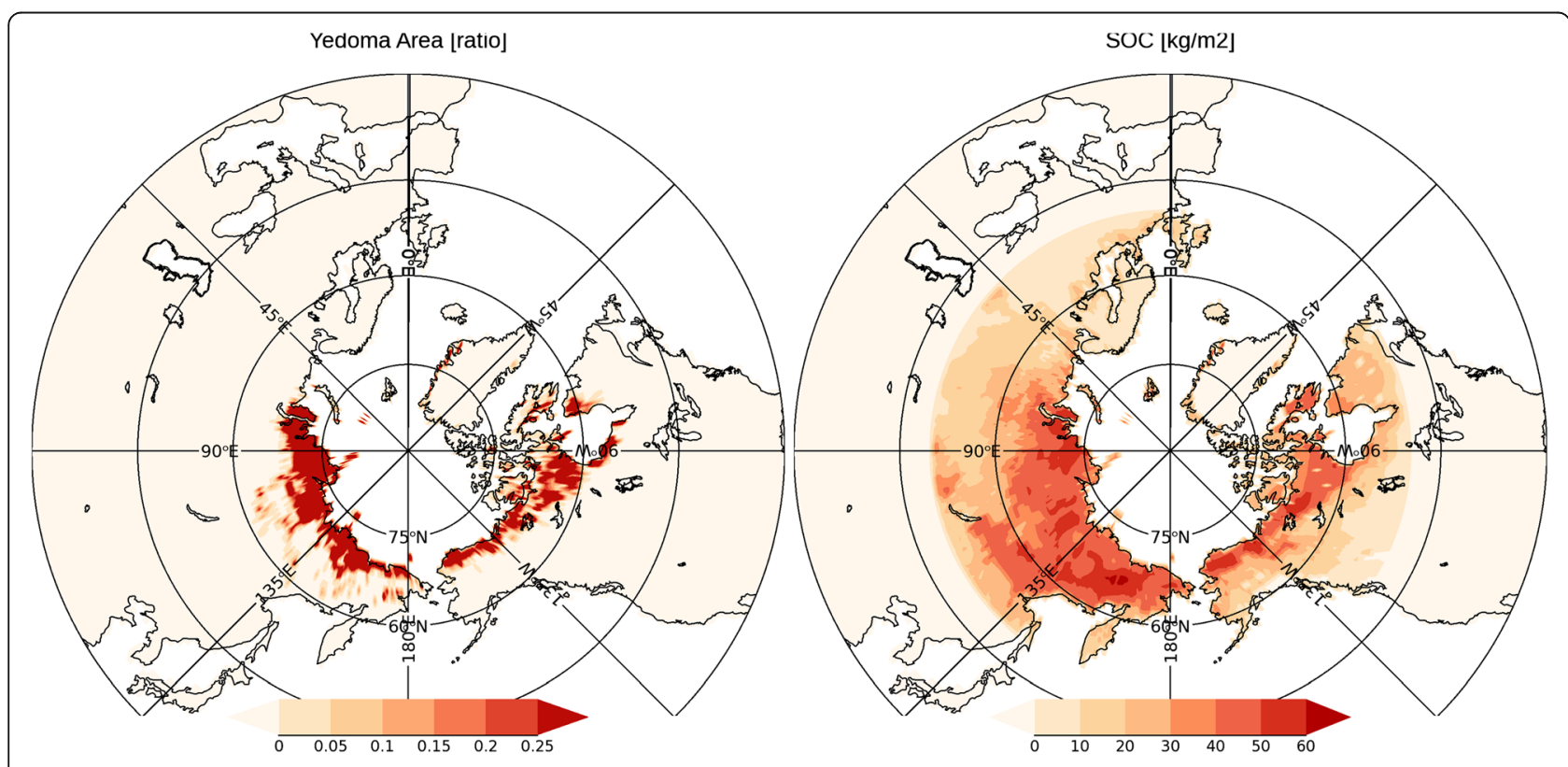

Fig. 1 (Left) Yedoma area used in the model simulation (unit = ratio to grid area); (right) soil organic carbon used in the model simulation (unit = kg/ $\mathrm{m}^{2}$ ) 
Table 3 shows the cumulative emissions of $\mathrm{CO}_{2}$ and $\mathrm{CH}_{4}$ due to the dynamic and thermodynamic degradation of the permafrost in the RCP8.5 scenario. Before conducting our future experiments, we confirmed that the average value of $\mathrm{CH}_{4}$ emission $\left(3.9 \mathrm{TgCH}_{4}\right)$ for the 5 -year period from the start year (2006) of the calculation is close to the estimate of present $\mathrm{CH}_{4}$ emission ( $4 \mathrm{TgCH}_{4}$, Walter Anthony et al. 2016; $1 \mathrm{TgCH}_{4}$, Saunois et al. 2020). As indicated in Table 3, the $\mathrm{CO}_{2}$ and $\mathrm{CH}_{4}$ releases due to the dynamic degradation (direct plus secondary emissions) of the Yedoma layer are approximately $0.1 \mathrm{PgC}$ and $5 \mathrm{TgCH} 4$, respectively. In each case, this is less than $1 \%$ of the total release due to dynamic and thermodynamic degradation (47 PgCO2 and $2067 \mathrm{TgCH} 4$, respectively). Comparing the direct release of GHGs trapped in the ground ice and frozen soil and the secondary release of GHG due to the decomposition of soil organic carbon, the latter is an order of magnitude larger than the former (Table 3). Even though very high concentrations of $\mathrm{CO}_{2}$ and $\mathrm{CH}_{4}$ are contained in the ground ice and frozen soil of the Yedoma layer (Saito et al. 2017), their impact on the climate is quite small when they are released into the atmosphere by the degradation of the permafrost. In the present formulation and over the study period (up to 2100), the dynamic degradation of the Yedoma layer does not significantly affect the carbon cycle feedback.

As shown in Table 3, the cumulative $\mathrm{CO}_{2}$ and $\mathrm{CH}_{4}$ emissions (the emissions due to dynamic and thermodynamic degradation) in the RCP8.5 scenario estimated in the present study are $47 \mathrm{PgC}$ (31-63 PgC, 68\% range) and 2067 (1261-2821) $\mathrm{TgCH} 4$, respectively. For comparison, Table 3 also shows the amount of GHG gas emissions estimated in various previous studies. As can be seen in the table, these estimated emissions cover a wide range. Notably, the GHG emissions for the RCP8.5 scenario estimated in the present study are within the indicated range of uncertainty. As shown in the table, the aggregated carbon content of $\mathrm{CO}_{2}$ plus $\mathrm{CH}_{4}$ emissions due to permafrost degradation in the present study is 48 (32-66) $\mathrm{PgC}$, and the increase in surface air temperature due to permafrost degradation is 0.08 (0.05-0.11) ${ }^{\circ} \mathrm{C}$. Other studies (e.g., Schaefer et al. 2014; Schneider von Deimling et al. 2015; Koven et al. 2015; Gasser et al. 2018) have reported similar values. One multi-model study featuring state-of-the-art process models reported that in some of the models, atmospheric carbon may actually be absorbed due to permafrost degradation owing to the effect of potential plant growth after thawing (McGuire et al. 2018). The spread in estimated GHG emissions in McGuire et al. 2018 is larger than in other studies, ranging from a carbon sink of $41 \mathrm{PgC}$ to a carbon source of $140 \mathrm{PgC}$ at the end of the twenty-first century. On the other hand, the amount of $\mathrm{CH} 4$ released in the $\mathrm{RCP} 8.5$ scenario in the present study is larger than the $1474 \mathrm{TgCH}_{4}$ reported by Schneider von Deimling et al. (2015).

Table 4 shows estimates of GHG emissions in the RCP2.6 scenario. Even here, the dynamic degradation of the Yedoma layer contributes less than 1\% to total GHG emissions, and the direct release of dynamic degradation is an order of magnitude smaller than the secondary release. As in the RCP8.5 scenario, the cumulative emissions of $\mathrm{CO}_{2}$ and $\mathrm{CH}_{4}$ resulting from the combined effect of dynamic and thermodynamic degradation are similar to those in previous studies. In the present study,

Table 3 Future predictions of GHG emissions from permafrost degradation in the RCP8.5 scenario

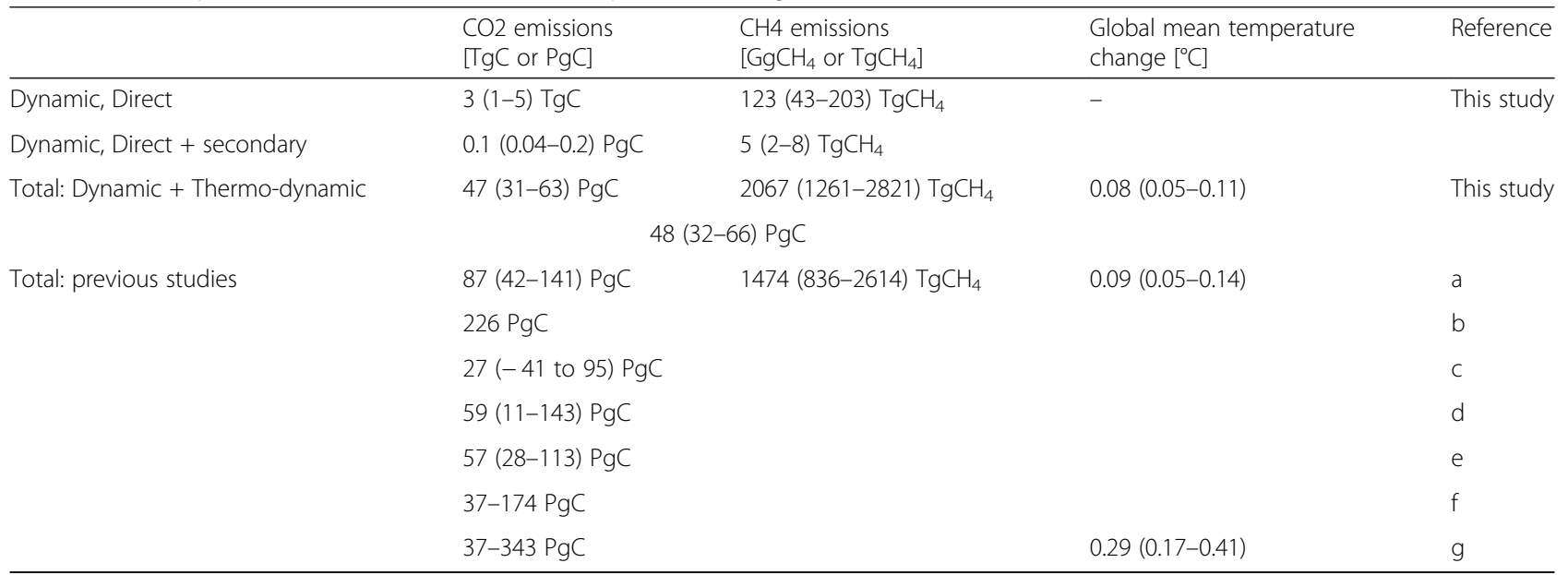

The cumulative $\mathrm{CO}_{2}$ and $\mathrm{CH}_{4}$ emissions are estimated at the end of twenty-first century. Direct emissions due to dynamic degradation, direct plus secondary emissions due to dynamic degradation, and total emissions due to dynamic plus thermodynamic degradation in the current study are shown (average value and 68th percentile range of model ensemble simulations). Some estimated values reported in previous studies are also shown in the far right column. References for the estimate in the previous studies are as follows. a: Schneider von Deimling et al. (2015), b: MacDougall et al. (2015), c: McGuire et al. (2018), d: Gasser et al. (2018), e: Koven et al. (2015), f: Schuur et al. (2015), g: Schaefer et al. (2014) 
Table 4 Same as Table 3, but for the RCP2.6 scenario

\begin{tabular}{|c|c|c|c|c|}
\hline & $\begin{array}{l}\text { CO2 emissions } \\
{[\mathrm{TgC} \text { or } \mathrm{PgC}]}\end{array}$ & $\begin{array}{l}\mathrm{CH} 4 \text { emissions } \\
{\left[\mathrm{GgCH}_{4} \text { or } \mathrm{TgCH}_{4}\right]}\end{array}$ & $\begin{array}{l}\text { Global mean temperature } \\
\text { change }\left[{ }^{\circ} \mathrm{C}\right]\end{array}$ & Reference \\
\hline Dynamic, Direct & $1(0.4-2) \mathrm{TgC}$ & 48 (17-81) GgCH4 & - & This study \\
\hline Dynamic, Direct + secondary & $0.07(0.03-0.1) \mathrm{PgC}$ & $3(1-5) \mathrm{TgCH} 4$ & & \\
\hline \multirow[t]{2}{*}{ Total: Dynamic + Thermo-dynamic } & $21(14-28) \mathrm{PgC}$ & $986(618-1341) \mathrm{TgCH}_{4}$ & $0.05(0.03-0.07)$ & This study \\
\hline & & ) $\mathrm{PgC}$ & & \\
\hline \multirow[t]{4}{*}{ Total: Previous studies } & $36(20-58) \mathrm{PgC}$ & 446 (218-921) TgCH4 & $0.06(0.03-0.10)$ & a \\
\hline & $103 \mathrm{PgC}$ & & & $b$ \\
\hline & $27(6-62) \mathrm{PgC}$ & & & $d$ \\
\hline & $56(13-118) \mathrm{PgC}$ & & & h \\
\hline
\end{tabular}

References for the estimate in the previous studies are as follows. a: Schneider von Deimling et al. (2015), b: MacDougall et al. (2015), d: Gasser et al. (2018), h: MacDougall and Knutti (2016)

the combined carbon content of $\mathrm{CO}_{2}$ and $\mathrm{CH}_{4}$ emissions is $22(15-29) \mathrm{PgC}$, which is similar to the total $27 \mathrm{PgC}$, reported by Gasser et al. (2018). On the other hand, the amount of released $\mathrm{CH}_{4}$ is 986 (618-1341) $\mathrm{TgCH}_{4}$, which is larger than the $446 \mathrm{TgCH} 4$ estimated in Schneider von Deimling et al. (2015). The increase in surface air temperature due to permafrost degradation is $0.05(0.03-0.07){ }^{\circ} \mathrm{C}$, which is similar to the $0.06(0.03-$ $0.10){ }^{\circ} \mathrm{C}$ estimated in Schneider von Deimling et al. (2015).

Figure 2 shows the cumulative GHG release due to dynamic permafrost degradation. In the formulation of dynamic degradation, GHG emissions are dependent on the possibility of fire $\left(P_{d s t r b}\right.$ in Eq. 4$)$ and the subsidence velocity of the land surface $\left(V_{d s t r b}\right)$, both of which are based on present observation (Section 2.1.1). Since we use the same $V_{d s t r b}$ for the RCP8.5 and RCP2.6 scenarios, the difference between the scenarios in Fig. 2 can be attributed to the difference in $P_{d s t r b}$. In our study, the possibility of fire is increased mainly due to temperature rise, as shown in Fig. 3, since $P_{d s t r b}$ is estimated as a function of meteorological data (Eq. 4) based on the relationship established from historical data (Veraverbeke et al. 2017).

Figure 4 shows the results of the cumulative release of GHG from the combination of dynamic and thermodynamic degradation. As described above, since the contribution of dynamic degradation of the Yedoma layer is less than $1 \%$ of the total, the cumulative emission is essentially determined by thermodynamic degradation (Section 2.1.2). This thermodynamic degradation is obtained by solving the equation of secondary release shown in Eq. (8), based on Eqs. (9)-(10). Here, the change in active layer thickness (ALT) simulated by the global land surface model (Yokohata et al. 2020a, 2020b)

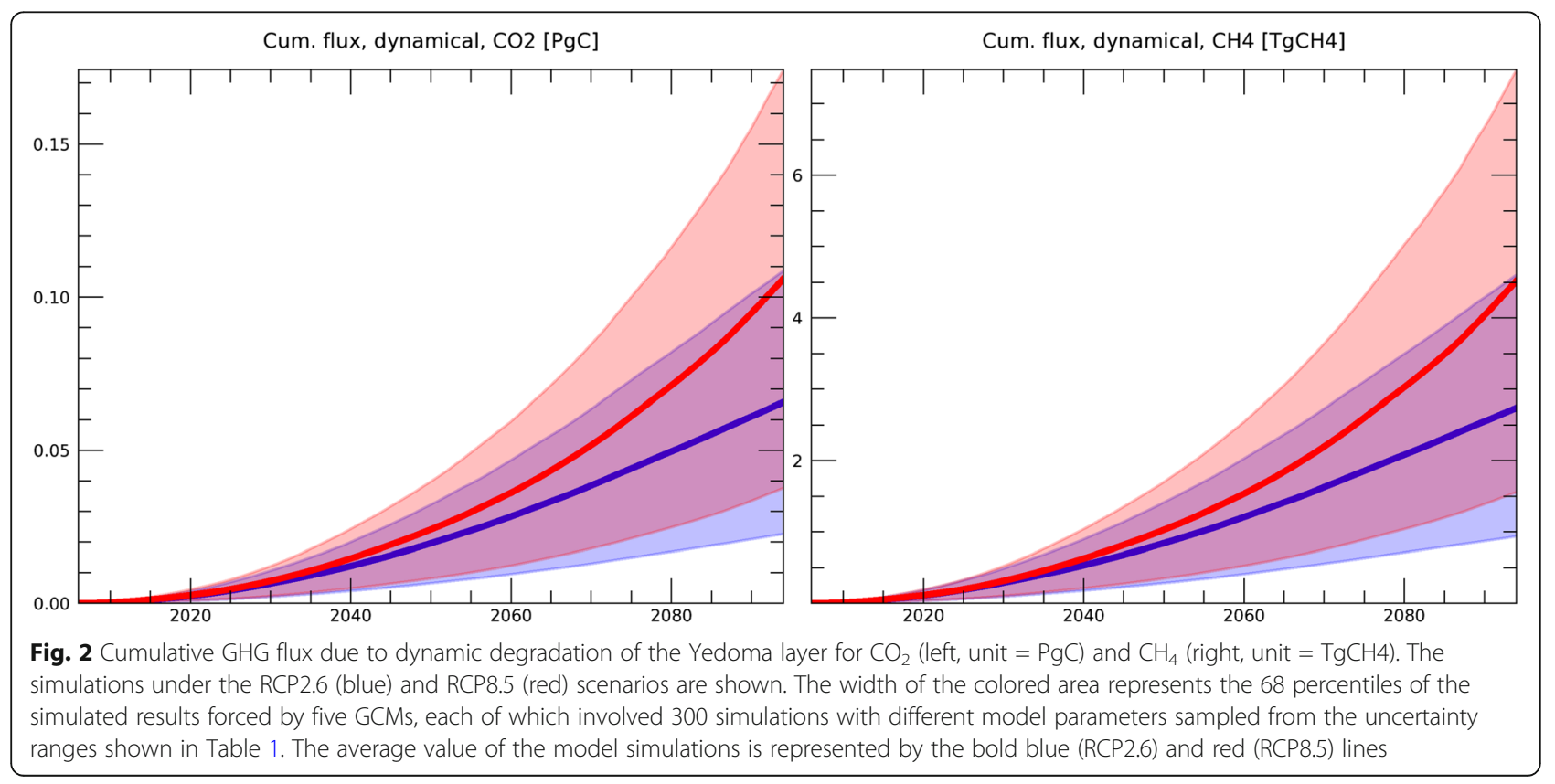


Fire burnt area [\%]

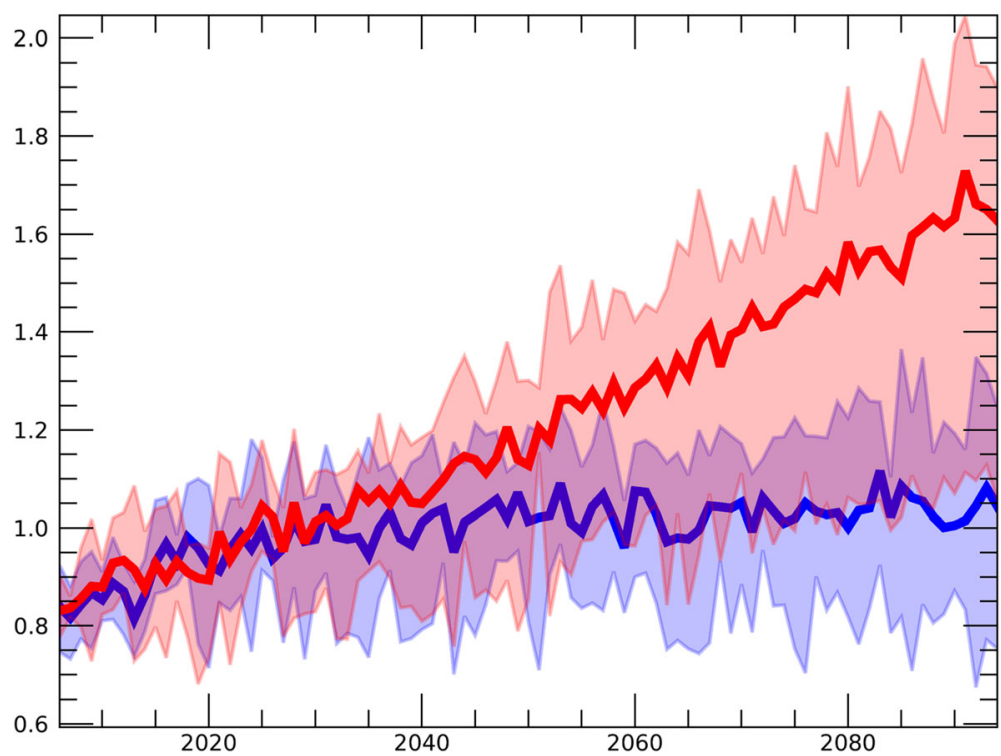

Fig. 3 Time sequence for the probability of fire in the RCP8.5 (red) and RCP2.6 (blue) scenarios. Unit is the ratio (\%) to the total land area above $50^{\circ} \mathrm{N}$. The width of the colored area represents the 68 percentiles of the 300 simulations with different model parameters, as explained in Section 2.1.1. The average value of the model simulations is represented by the bold blue (RCP2.6) and red (RCP8.5) lines

is used for the calculation of permafrost degradation. As shown in Fig. 4, the cumulative release of $\mathrm{CO}_{2}$ from permafrost degradation increases almost linearly in RCP2.6, but the rate of increase rises in RCP8.5 in the latter half of the twenty-first century. This is due to the fact that the permafrost area rapidly decreases in RCP8.5 in the latter half of the century in these simulations (the details of the land surface model simulation results are provided in Yokohata et al. 2020b).
Figure 5 shows the $\mathrm{CO}_{2}$ and $\mathrm{CH}_{4}$ emissions at the end of the twenty-first century in the RCP8.5 scenario. We found that $\mathrm{CO}_{2}$ emissions are more widespread compared to the confined emissions of $\mathrm{CH}_{4}$. This is related to the fact that $\mathrm{CH}_{4}$ emissions can be larger in a wetland region, and the regions with a high wetland ratio are limited. The important factors that determine thermodynamic degradation are changes in the active layer thickness (Eq. 10) and the rise of soil temperature (Eq. 7).

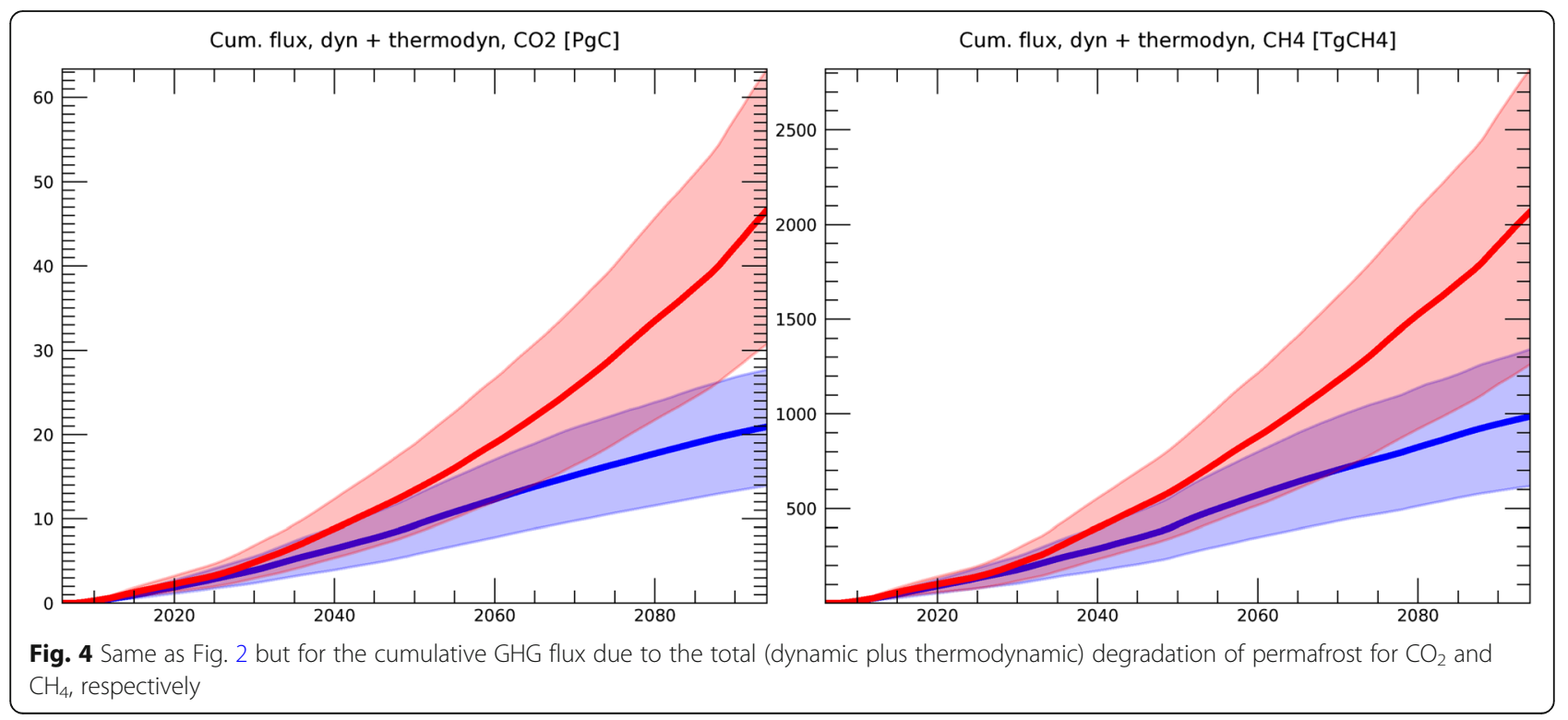




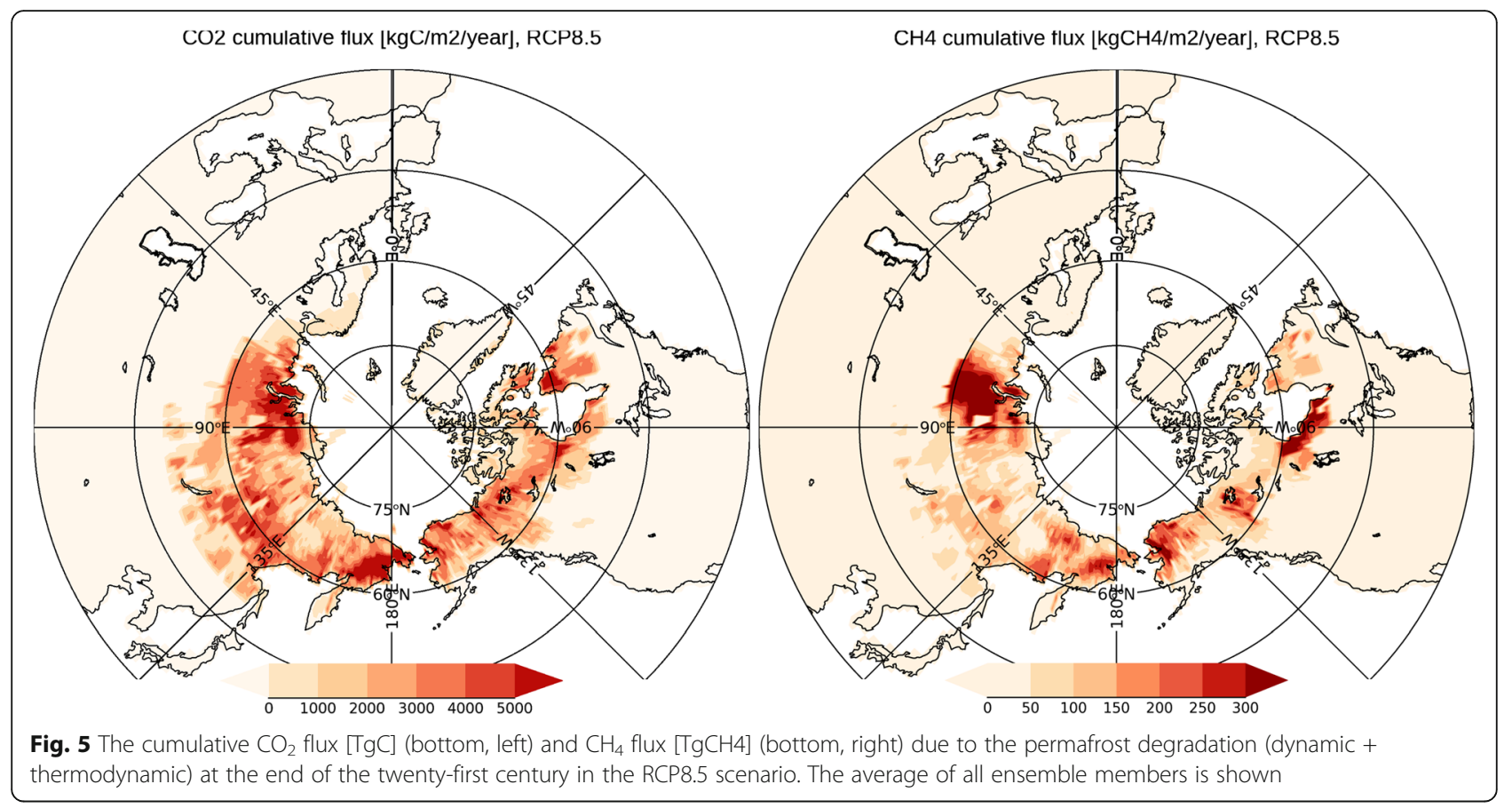

In order to interpret the results in Fig. 5, the changes in the active layer thickness, permafrost area, and wetland fraction are shown in Fig. 6. As indicated in the figure, the changes in active layer thickness are large in western and eastern Siberia, and in the North America coastal regions of the Arctic Ocean. This distribution roughly corresponds to that of $\mathrm{CO}_{2}$ emissions (Fig. 5). In western and eastern Siberia, and the northern part of North America, the amount of $\mathrm{CH}_{4}$ emission is large in regions with a large wetland fraction (Fig. 6).

Figure 6 also shows the changes in the permafrost area, which corresponds to the region with temperatures below $0{ }^{\circ} \mathrm{C}$ throughout the year. In the regions where the permafrost area decreased, the area below $0{ }^{\circ} \mathrm{C}$ throughout the year decreased. Figure 6 indicates that the permafrost area decreases significantly in the western and southern part of eastern Siberia, while permafrost remains in a wide region from the center to eastern Siberia. In other words, at the end of the twenty-first century, permafrost will remain in the cold regions, with the expectation that thawing will progress in the twentysecond century. Previous studies have reported that the impact of permafrost degradation on the climate will be greater after the end of the twenty-first century (e.g., McGuire et al. 2018), which is consistent with our result.

\section{Conclusions}

In this study, we developed PDGEM, a model for estimating GHG emissions due to permafrost degradation. Using the model, we produced future projections of the following three processes: (a) Direct release of GHGs due to the dynamic degradation of the Yedoma layer: The process in which high concentrations of $\mathrm{CO}_{2}$ and $\mathrm{CH}_{4}$ trapped in the ground ice and frozen soil of the Yedoma layer are released due to dynamic degradation.

(b) Secondary release of GHGs due to the dynamic degradation of the Yedoma layer: The process by which organic matter trapped in the Yedoma layer is newly decomposed by the thawing of the permafrost to release $\mathrm{CO}_{2}$ and $\mathrm{CH}_{4}$.

(c) Secondary release of GHGs due to the thermodynamic degradation of permafrost: The process by which organic matter trapped in the permafrost is newly decomposed by the thawing of the permafrost to release $\mathrm{CO}_{2}$ and $\mathrm{CH}_{4}$.

In the RCP8.5 and RCP2.6 scenarios, numerical simulations through the twenty-first century showed that the combination of (a) plus (b) contributed less than $1 \%$ of the total emissions resulting from $(a)+(b)+(c)$. It was also found that the contribution of (a) is an order of magnitude smaller than that of (b). The cumulative release of $\mathrm{CO}_{2}$ plus $\mathrm{CH}_{4}$ produced by (a) $+(\mathrm{b})+(\mathrm{c})$ was 48 (32-66) PgC for RCP8.5, and 22 (15-29) PgC for RCP2.6. This is consistent with a recent multi-model study (-41 to $95 \mathrm{GtC}$, McGuire et al. 2018) which reported that in one of the ESMs, the land becomes a carbon sink owing to the effect of plant growth after thawing.

In this study, dynamic degradation of the Yedoma layer (defined as the location of high soil organic carbon 


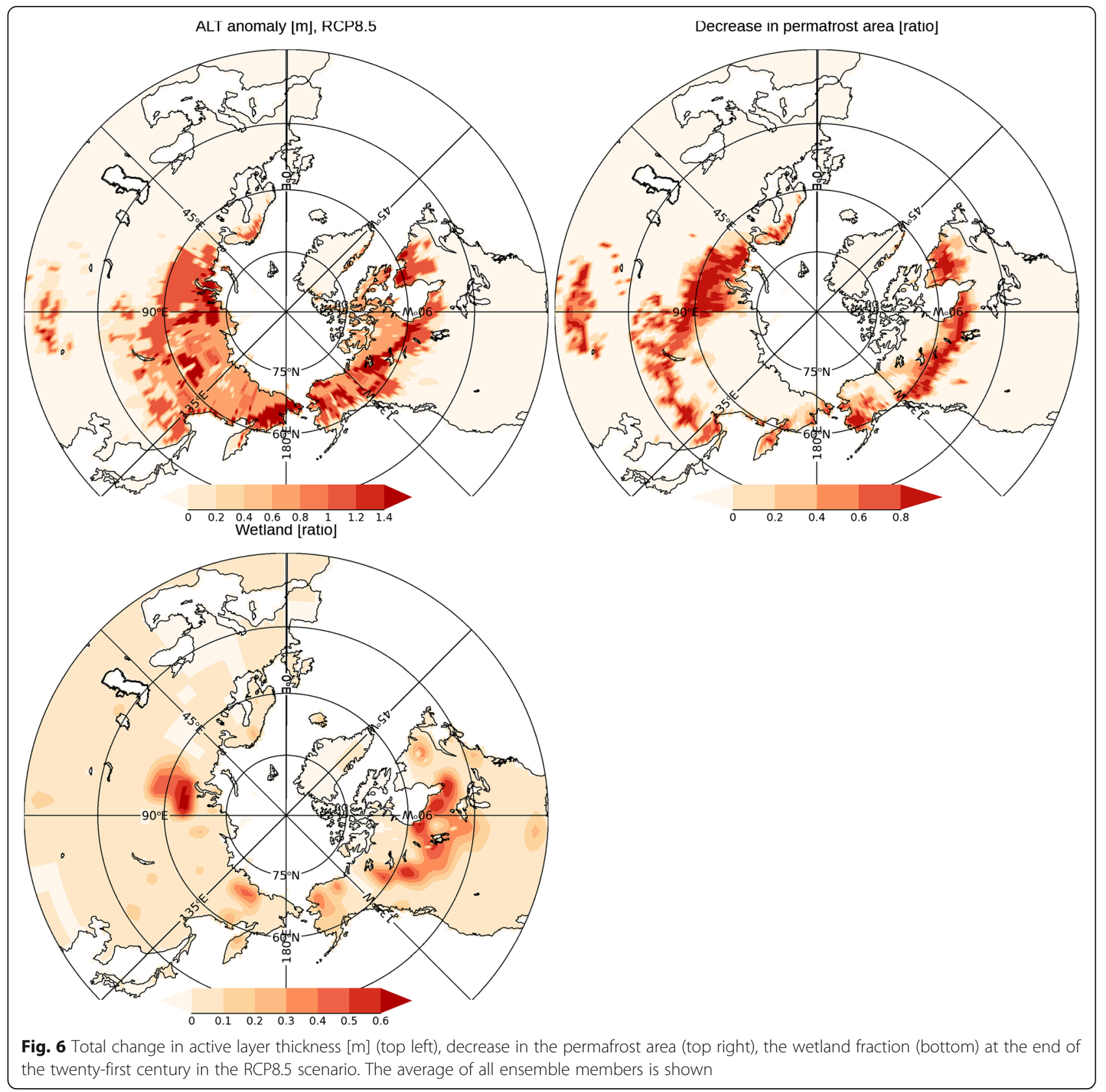

and soil frozen water) is formulated by the possibility of fire $\left(P_{d s t r b}\right)$ and the present land surface subsidence velocity $\left(V_{d s t r b}\right)$ as shown in Eq. (3). The contribution of dynamic degradation $((\mathrm{a})+(\mathrm{b})$ above) is small since the area ratio of the Yedoma layer $\left(A_{y d m}\right)$ is very small. The contribution of dynamic degradation will be large if the dynamic degradation (i.e., the subsidence of surface due to dynamic collapse) occurs outside the Yedoma layer, or if the subsidence velocity is higher than it is currently. To estimate the probability of fire, the relationship between the occurrence of fire and meteorological conditions (Eq. 4) constructed from observation data is used; however, if the relationship described in Eq. (4) is different in the future, the frequency of fires will also change.

With PDGEM, the global distribution of GHG emissions can be estimated (e.g., Fig. 5) by using the thawing process of permafrost obtained from a state-of-the-art land surface model (Yokohata et al. 2020a, 2020b), taking into account the substantial uncertainties associated with the model's parameters (Table 1) and future atmospheric changes. This represents a significant advantage when compared to previous related studies (e.g., Schneider von Deimling et al. 2015; Gasser et al. 2018; McGuire et al. 2018). The models of permafrost degradation in previous studies were unable to predict the geographic 
distribution of GHG emissions due to their simplification of physical processes (Schneider von Deimling et al. 2015; Gasser et al. 2018). On the other hand, for state-of-the-art earth system models that incorporate advanced physical and carbon cycle processes (McGuire et al. 2018), it is difficult to fully consider the uncertainties in model prediction such as the uncertainties in future atmospheric responses. In this study, combining a simple scheme of carbon cycle processes with the results of the latest land surface model makes it possible to project the geographical distribution of future GHG emissions due to permafrost degradation (Fig. 5) by considering, across a very broad range, the uncertainties associated with the various model parameters and future atmospheric responses.

In the previous studies (e.g., Gasser et al. 2018), it has been shown that GHG emissions caused by the thawing of permafrost can be an obstacle to achieving the climate stabilization called for in the Paris Agreement. In addition, as described in Fig. 6, substantial permafrost remains unthawed at the end of the twenty-first century, and thus the impact of GHG gas emissions from permafrost thawing on the climate system is expected to increase markedly after that time (McGuire et al. 2018). As discussed in Section 4, the geographical distributions of GHG emissions (Fig. 5) are connected to changes in ground temperature, soil moisture status and wetland distribution, and the soil carbon accumulated over time scales of past glacial cycles. The hotspots with particularly large GHG emissions shown in Fig. 5 are determined by the interactions between these factors investigated in this study. In the regions of GHG emission hotspots shown in Fig. 5 , it may be possible to reduce GHG emissions by taking measures such as restricting land development.

\section{Abbreviations}

ALT: Active layer thickness; CLAM: Circumpolar active layer monitoring; CMIP: Coupled Model Inter-comparison Project; GCM: Global climate model; GHGs: Greenhouse gases; IPA: International Permafrost Association; ISIMIP: Inter-Sectoral Impact Model Inter-comparison Project; MATS IRO: Minimal advanced treatments of surface interaction and runoff; MIROC: Model for Interdisciplinary Research on Climate; PDGEM: Permafrost Degradation and Greenhouse gases Emission Model; RCP: Representative concentration pathways

\section{Acknowledgements \\ We gratefully acknowledge the helpful discussions with Hideo Shiogama, Tomoo Ogura, Nagio Hirota, Kaoru Tachiiri, and Michio Kawamiya. The authors are much indebted to Keita Matsumoto, Kuniyasu Hamada, Kenryou Kataumi, Eiichi Hirohashi, Futoshi Takeuchi, Nobuaki Morita, and Kenji Yoshimura at NEC Corporation for their support in model development. Model simulations were performed on the SGI UV20 at the National Institute for Environmental Studies. NCEP Reanalysis Derived data provided by the NOAA/OAR/ESRL PSL, Boulder, Colorado, USA, from their Web site at https://psl.noaa.gov/.}

\section{Authors' contributions}

TY and KS proposed the topic and conceived and designed the study. TY, $\mathrm{KS}$, and $\mathrm{Al}$ contributed to the formulation of the numerical model. TY and KT carried out the experimental study and analyzed the results of the numerical simulations. $\mathrm{HO}$ and $\mathrm{Gl}$ provided the observational data. All authors have read and approved the final manuscript.

\section{Funding}

This study was conducted as a part of the Environment Research and Technology Development Fund project (2-1605, JPMEERF20162005) "Assessing and Projecting Greenhouse Gas Release from Large-scale Permafrost Degradation" supported by the Ministry of Environment and the Environmental Restoration and Conservation Agency. Our research is also supported by the "Integrated Research Program for Advancing Climate Models (TOUGOU Program)" sponsored by the Ministry of Education, Culture, Sports, Science and Technology (MEXT), Japan. This study was partly supported by the NASA ABoVE (Arctic Boreal and Vulnerability Experiment (grant no. NNX17AC57A)). KT benefited from State assistance managed by the National Research Agency in France under the "Programme d'Investissements d'Avenir" under the reference "ANR-19-MPGA-0008".

\section{Availability of data and materials}

Data sharing is not applicable to this article as no datasets were generated or analyzed during the current study. Please contact the authors for data requests.

\section{Competing interests}

The authors declare that they have no competing interest.

\section{Author details}

${ }^{1}$ Center for Global Environmental Research, National Institute for Environmental Studies, 16-2 Onogawa, Tsukuba 305-8506, Japan. ${ }^{2}$ Research Center for Environmental Modeling and Application, Japan Agency for Marine-Earth Science and Technology, 3173-25 Showamachi, Kanazawaku, Yokohama 236-0001, Japan. ${ }^{3}$ School of Earth, Energy and Environmental Engineering, Kitami Institute of Technology, 165 Koen-cho, Kitami 090-8507, Japan. ${ }^{4}$ Laboratoire des Sciences du Climat et de I'Environnement (LSCE), Commissariat à l'énergie atomique et aux énergies alternatives (CEA), Gif-sur-Yvette, France. ${ }^{5}$ International Arctic Research Center, 739, The University of Alaska Fairbanks, 2160 Koyukuk Dr, Fairbanks, AK 740 99775-7340, USA.

Received: 30 December 2019 Accepted: 20 August 2020

Published online: 02 October 2020

\section{References}

Anthony KMW, Zimov SA, Grosse G et al (2014) A shift of thermokarst lakes from carbon sources to sinks during the Holocene epoch. Nature 511(7510):452456. https://doi.org/10.1038/nature13560

Bentsen M, Bethke I, Debernard JB et al (2013) The Norwegian Earth system model, NorESM1-M - part 1: description and basic evaluation of the physical climate. Geosci Model Dev 6(3):687-720. https://doi.org/10.5194/ gmd-6-687-2013

Brouchkov A, Fukuda M (2002) Preliminary measurements on methane content in permafrost, Central Yakutia, and some experimental data. Permafrost and Periglacial Processes 13(3):187-197. https://doi.org/10.1002/ppp.422

Brown A (2013) Pandora's freezer? Nature Climate Change 3(5):442-442. https:// doi.org/10.1038/nclimate1896

Burke EJ, Hartley IP, Jones CD (2012) Uncertainties in the global temperature change caused by carbon release from permafrost thawing. The Cryosphere 6(5):1063-1076. https://doi.org/10.5194/tc-6-1063-2012

Ciais P, Sabine C, Bala G, Bopp L, Brovkin V, Canadell J et al (2013) Carbon and other biogeochemical cycles. In: Climate Change 2013: The physical science basis contribution of working group I to the Fifth Assessment Report of the Intergovernmental Panel on Climate Change. Cambridge Univ. Press, Cambridge, United Kingdom and New York, NY, USA, pp 465-570

Collins M, Knutti R, Arblaster J, Dufresne J-L, Fichefet T, Friedlingstein P, et al. (2013) Long-term climate change: Projections, commitments and irreversibility. In Stocker TF, et al. (Eds.), Climate Change 2013: The Physical Science Basis. Contribution of Working Group I to the Fifth Assessment Report of the Intergovernmental Panel on Climate Change. New York NY USA: Cambridge University Press (pp. 1029-1136)

Dlugokencky E, Tans PP (2013) Globally averaged marine surface annual mean data, NOAA/ESRL. In. www.esrl.noaa.gov/gmd/ccgg/trends/, Accessed 01-0220132013

Dufresne J-L, Foujols M-A, Denvil S et al (2013) Climate change projections using the IPSL-CM5 Earth System Model: from CMIP3 to CMIP5. Climate Dynamics 40(9):2123-2165. https://doi.org/10.1007/s00382-012-1636-1 
Dunne JP, John JG, Adcroft AJ et al (2012) GFDL's ESM2 global coupled climatecarbon Earth System Models Part I: Physical formulation and baseline simulation characteristics. Journal of Climate 25(19):6646-6665. https://doi. org/10.1175/JCLI-D-11-00560.1

Dutta K, Schuur EAG, Neff JC, Zimov SA (2006) Potential carbon release from permafrost soils of Northeastern Siberia. Global Change Biology 12(12):23362351. https://doi.org/10.1111/j.1365-2486.2006.01259.x

Gasser T, Kechiar M, Ciais P et al (2018) Path-dependent reductions in CO2 emission budgets caused by permafrost carbon release. Nature Geoscience 11(11):830-835. https://doi.org/10.1038/s41561-018-0227-0

Günther F, Overduin PP, Sandakov AV, Grosse G, Grigoriev MN (2013) Shortand long-term thermo-erosion of ice-rich permafrost coasts in the Laptev Sea region. Biogeosciences 10(6):4297-4318. https://doi.org/10. 5194/bg-10-4297-2013

Hempel S, Frieler K, Warszawski L, Schewe J, Piontek F (2013) A trend-preserving bias correction \&ndash; the ISI-MIP approach. Earth System Dynamics 4(2): 219-236. https://doi.org/10.5194/esd-4-219-2013

Hugelius G, Tarnocai C, Broll G, Canadell JG, Kuhry P, Swanson DK (2013) The Northern Circumpolar soil carbon database: spatially distributed datasets of soil coverage and soil carbon storage in the northern permafrost regions. Earth Syst Sci Data 5(1):3-13. https://doi.org/10.5194/essd-5-3-2013

Hugelius G, Strauss J, Zubrzycki S et al (2014) Estimated stocks of circumpolar permafrost carbon with quantified uncertainty ranges and identified data gaps. Biogeosciences 11(23):6573-6593. https://doi.org/10. 5194/bg-11-6573-2014

IPCC, 2013: Annex III: Glossary [Planton, S. (ed.)]. In: Climate Change 2013: the physical science basis. Contribution of Working Group I to the Fifth Assessment Report of the Intergovernmental Panel on Climate Change [Stocker, T.F., D. Qin, G.-K. Plattner, M. Tignor, S.K. Allen, J. Boschung, A. Nauels, Y. Xia, V. Bex and P.M. Midgley (eds.)]. Cambridge University Press, Cambridge, United Kingdom and New York, NY, USA.

Iwahana G, Harada K, Uchida M et al (2016) Geomorphological and geochemistry changes in permafrost after the 2002 tundra wildfire in Kougarok, Seward Peninsula, Alaska. Journal of Geophysical Research: Earth Surface 121(9):16971715. https://doi.org/10.1002/2016jf003921

Jones CD, Hughes JK, Bellouin N et al (2011) The HadGEM2-ES implementation of CMIP5 centennial simulations. Geosci Model Dev 4(3):543-570. https://doi. org/10.5194/gmd-4-543-2011

Kalnay E, Kanamitsu M, Kistler R et al (1996) The NCEP/NCAR 40-Year Reanalysis Project. Bulletin of the American Meteorological Society 77(3):437-472. https://doi.org/10.1175/1520-0477

Kanevskiy M, Shur Y, Fortier D, Jorgenson MT, Stephani E (2011) Cryostratigraphy of late Pleistocene syngenetic permafrost (yedoma) in northern Alaska, Itkillik River exposure. Quaternary Research 75(3):584-596. https://doi.org/10.1016/j. yqres.2010.12.003

Kanevskiy M, Shur Y, Strauss J, Jorgenson T, Fortier D, Stephani E, Vasiliev S (2016) Patterns and rates of riverbank erosion involving ice-rich permafrost (yedoma) in northern Alaska. Geomorphology, 253:370-84

Kawamiya M, Hajima T, Tachiiri K, Yokohata T (2020) Two decades of Earth system modelling, submitted to the same issue of Progress in Earth and Planetary Science.

Köhler P, Knorr G, Bard E (2014) Permafrost thawing as a possible source of abrupt carbon release at the onset of the Bølling/Allerød. Nature communications 5(1):5520. https://doi.org/10.1038/ncomms6520

Koven CD, Ringeval B, Friedlingstein P et al (2011) Permafrost carbon-climate feedbacks accelerate global warming. Proceedings of the National Academy of Sciences of the United States of America 108(36):14769-14774. https://doi. org/10.1073/pnas.1103910108

Koven CD, Riley WJ, Stern A (2013) Analysis of permafrost thermal dynamics and Response to climate change in the CMIP5 Earth system models. Journal of Climate 26(6):1877-1900. https://doi.org/10.1175/jcli-d-12-00228.1

Koven CD, Schuur EA, Schadel C et al (2015) A simplified, data-constrained approach to estimate the permafrost carbon-climate feedback. Philosophical transactions Series A, Mathematical, physical, and engineering sciences 373(2054). https://doi.org/10.1098/rsta.2014.0423

Lee $H$, Schuur EAG, Inglett KS, Lavoie M, Chanton JP (2012) The rate of permafrost carbon release under aerobic and anaerobic conditions and its potential effects on climate. Global Change Biology 18(2):515-527. https:// doi.org/10.1111/j.1365-2486.2011.02519.x
Lehner B, Döll P (2004) Development and validation of a global database of lakes, reservoirs and wetlands. Journal of Hydrology 296(1):1-22. https://doi. org/10.1016/j.jhydrol.2004.03.028

Lenton TM, Held H, Kriegler E, Hall JW, Lucht W, Rahmstorf S, Schellnhuber HJ (2008) Tipping elements in the Earth's climate system. Proc Natl Acad Sci U S A 105:1786-93

MacDougall AH, Knutti R (2016) Projecting the release of carbon from permafrost soils using a perturbed parameter ensemble modelling approach. Biogeosciences 13:2123-36

MacDougall AH, Zickfeld K, Knutti R, Matthews HD (2015) Sensitivity of carbon budgets to permafrost carbon feedbacks and non-CO2 forcings. Environmental Research Letters 10(12):125003. https://doi.org/10.1088/17489326/10/12/125003

McGuire AD, Lawrence DM, Koven C et al (2018) Dependence of the evolution of carbon dynamics in the northern permafrost region on the trajectory of climate change. Proceedings of the National Academy of Sciences of the United States of America 115(15):3882-3887. https://doi.org/10.1073/pnas.1719903115

Nitta T, Yoshimura K, Takata K et al (2014) Representing variability in subgrid snow cover and snow depth in a global land model: offline validation. Journal of Climate 27(9):3318-3330. https://doi.org/10.1175/jcli-d-13-00310.1

Ping C-L, Michaelson GJ, Jorgenson MT et al (2008) High stocks of soil organic carbon in the North American Arctic region. Nature Geoscience 1(9):615-619. https://doi.org/10.1038/ngeo284

Prentice IC, Farquhar GD, Fasham MJR et al (2001) The carbon cycle and atmospheric carbon dioxide, contribution of working group I to the third assessment report of the Intergovernmental Panel on Climate Change. In: Houghton JT, Ding Y, Griggs DJ et al (eds) Climate Change 2001: The Scientific Basis. Cambridge University Press, Cambridge, United Kingdom and New York, pp 183-237

Saito K, Ohno H, Yokohata T, Iwahana G, Machiya H (2017) Assessing and projecting greenhouse gas release due to dynamic permafrost degradation. Paper presented at the 2017 Fall Conference of the American Geophysical Union, New Orleans Convention Center, New Orleans, 13 December 2017.

Saito K, Machiya H, Iwahana G, Ohno H, Yokohata T (2020) Mapping simulated circum-Arctic organic carbon, ground ice, and vulnerability of ice-rich permafrost to degradation. Progress in Earth and Planetary Science 7(1):31. https://doi.org/10.1186/s40645-020-00345-z

Saunois M, Stavert AR, Poulter B et al (2020) The Global Methane Budget 2000 2017. Earth Syst Sci Data 12(3):1561-1623. https://doi.org/10.5194/essd-121561-2020

Schädel C, Schuur EAG, Bracho R et al (2014) Circumpolar assessment of permafrost $C$ quality and its vulnerability over time using long-term incubation data. Global Change Biology 20(2):641-652. https://doi.org/10. $1111 /$ gcb. 12417

Schaefer K, Lantuit H, Romanovsky VE, Schuur EAG, Witt R (2014) The impact of the permafrost carbon feedback on global climate. Environmental Research Letters 9(8):085003. https://doi.org/10.1088/1748-9326/9/8/085003

Schirrmeister L, Grosse G, Wetterich S et al (2011) Fossil organic matter characteristics in permafrost deposits of the northeast Siberian Arctic. Journal of Geophysical Research: Biogeosciences 116(G2). https://doi.org/10.1029/ $2011 \mathrm{jg} 001647$

Schneider von Deimling T, Grosse G, Strauss J et al (2015) Observation-based modelling of permafrost carbon fluxes with accounting for deep carbon deposits and thermokarst activity. Biogeosciences 12(11):3469-3488. https:// doi.org/10.5194/bg-12-3469-2015

Schuur EAG, Bockheim J, Canadell JG et al (2008) Vulnerability of permafrost carbon to climate change: implications for the global carbon cycle. BioScience 58(8):701-714. https://doi.org/10.1641/b580807

Schuur EA, McGuire AD, Schadel C et al (2015) Climate change and the permafrost carbon feedback. Nature 520(7546):171-179. https://doi.org/10. 1038/nature14338

Segers R (1998) Methane production and methane consumption: a review of processes underlying wetland methane fluxes. Biogeochemistry 41(1):23-51. https://doi.org/10.1023/a:1005929032764

Sitch S, Smith B, Prentice IC et al (2003) Evaluation of ecosystem dynamics, plant geography and terrestrial carbon cycling in the LPJ Dynamic Global Vegetation Model. Global Change Biology 9(2):161-185. https://doi.org/10. 1046/j.1365-2486.2003.00569.x

Steffen W, Rockström J, Richardson K et al (2018) Trajectories of the Earth System in the Anthropocene. Proceedings of the National Academy of Sciences 115(33):8252-8259. https://doi.org/10.1073/pnas.1810141115 
Strauss J, Schirrmeister L, Grosse G et al (2013) The deep permafrost carbon pool of the Yedoma region in Siberia and Alaska. Geophysical Research Letters 40(23):6165-6170. https://doi.org/10.1002/2013GL058088

Strauss J, Schirrmeister L, Mangelsdorf K, Eichhorn L, Wetterich S, Herzschuh U (2015) Organic-matter quality of deep permafrost carbon - a study from Arctic Siberia. Biogeosciences 12:2227-45.

Strauss J, Schirrmeister L, Grosse G et al (2017) Deep Yedoma permafrost: a synthesis of depositional characteristics and carbon vulnerability. EarthScience Reviews 172:75-86. https://doi.org/10.1016/j.earscirev.2017.07.007

Takata K, Emori S, Watanabe T (2003) Development of the minimal advanced treatments of surface interaction and runoff. Global and Planetary Change 38(1-2):209-222. https://doi.org/10.1016/s0921-8181(03)00030-4

Tanaka K, O'Neill BC (2018) The Paris Agreement zero-emissions goal is not always consistent with the $1.5^{\circ} \mathrm{C}$ and $2{ }^{\circ} \mathrm{C}$ temperature targets. Nature Climate Change 8(4):319-324. https://doi.org/10.1038/s41558-018-0097-x

Tarnocai C, Canadell JG, Schuur EAG, Kuhry P, Mazhitova G, Zimov S (2009) Soil organic carbon pools in the northern circumpolar permafrost region. Global Biogeochemical Cycles 23:Gb2023. https://doi.org/10.1029/2008gb003327

Ulrich M, Grosse G, Strauss J, Schirrmeister L (2014) Quantifying wedge-ice volumes in Yedoma and Thermokarst Basin deposits. Permafrost and Periglacial Processes 25(3):151-161. https://doi.org/10.1002/ppp.1810

Veraverbeke S, Rogers BM, Goulden ML et al (2017) Lightning as a major driver of recent large fire years in North American boreal forests. Nature Climate Change 7(7):529-534. https://doi.org/10.1038/nclimate3329

Vonk JE, Sánchez-García L, van Dongen BE et al (2012) Activation of old carbon by erosion of coastal and subsea permafrost in Arctic Siberia. Nature 489(7414):137-140. https://doi.org/10.1038/nature11392

van Vuuren DP, Edmonds J, Kainuma M et al (2011) The representative concentration pathways: an overview. Climatic Change 109(1-2):5-31. https:// doi.org/10.1007/s10584-011-0148-z

Walter Anthony KM, Daanen R, Anthony P, Schneider von Deimling T, Ping C-L, Chanton JP, Grosse G (2016) Present-day permafrost carbon feedback from thermokarst lakes, in: EPIC3XI, International Conference on Permafrost, Potsdam, Germany, 20-24 June 2016. Potsdam, Germany

Walter BP, Heimann M (2000) A process-based, climate-sensitive model to derive methane emissions from natural wetlands: application to five wetland sites, sensitivity to model parameters, and climate. Global Biogeochemical Cycles 14(3):745-765. https://doi.org/10.1029/1999GB001204

Walter KM, Edwards ME, Grosse G, Zimov SA, Chapin FS (2007) Thermokarst lakes as a source of atmospheric methane during the last deglaciation. Science 318:633-636

Watanabe M, Suzuki T, O'ishi R et al (2010) Improved climate simulation by MIROC5: mean states, variability, and climate sensitivity. Journal of Climate 23(23):6312-6335. https://doi.org/10.1175/2010jcli3679.1

Watanabe S, Hajima T, Sudo K, et al. (2011) MIROC-ESM 2010: model description and basic results of CMIP5-20c3m experiments. Geosci Model Dev 4(4):845872 doi:https://doi.org/10.5194/gmd-4-845-2011

Yokohata T, Kinoshita T, Sakurai G, et al. (2020a) MIROC-INTEG-LAND version 1: A global bio-geochemical land surface model with human water management, crop growth, and land-use change. Geosci Model Dev, in press

Yokohata T, Saito K, Takata K, Nitta T, Sato Y, Hajima T, Sueyoshi T, Iwahana G (2020b) Model improvement and future projection of permafrost processes in a global climate model, Submitted to the same issue of Progress in Earth and Planetary Science

Zimov SA, Davydov SP, Zimova GM et al (2006a) Permafrost carbon: stock and decomposability of a globally significant carbon pool. Geophysical Research Letters 33(20). https://doi.org/10.1029/2006gl027484

Zimov SA, Schuur EAG, Chapin FS (2006b) Permafrost and the global carbon budget. Science 312(5780):1612-1613. https://doi.org/10.1126/science. 1128908

\section{Publisher's Note}

Springer Nature remains neutral with regard to jurisdictional claims in published maps and institutional affiliations.

\section{Submit your manuscript to a SpringerOpen ${ }^{\circ}$ journal and benefit from:}

- Convenient online submission

- Rigorous peer review

- Open access: articles freely available online

- High visibility within the field

- Retaining the copyright to your article

Submit your next manuscript at $\boldsymbol{\nabla}$ springeropen.com 